\title{
Negative Impact of 25-hydroxyvitamin D Deficiency on Breast Cancer Survival
}

\author{
Somchai Thanasitthichai ${ }^{1,2 *}$, Aree Prasitthipayong ${ }^{3}$, Krittika Boonmark ${ }^{2}$, Wichai \\ Purisa $^{2}$, Kamolchanok Guayraksa ${ }^{2}$
}

\begin{abstract}
Background: Low 25-hydroxyvitamin D [25(OH)D] levels in serum are associated with breast cancer risk. This study was conducted to determine the impact of $25(\mathrm{OH}) \mathrm{D}$ deficiency on survival of breast cancer patients. Methods: In a retrospective cohort study of 303 patients diagnosed with breast cancer during 2011-2012 at the National Cancer Institute Thailand, all cases were followed up for 7 years. The 25(OH)D was measured by high-performance liquid chromatography (HPLC). Clinical and pathological data were collected. The Chi-square test, Kaplan-Meier and Cox regression model were used to assess the association between $25(\mathrm{OH}) \mathrm{D}$ levels and risk of death. Results: Of the 303 cases aged between 24 and 78 years 51 (16.8\%) died during follow-up from any cause. The mean 25(OH)D levels was $25.1 \pm 7.54 \mathrm{ng} / \mathrm{ml}(8.2-61.0 \mathrm{ng} / \mathrm{ml})$. Thirty-three patients $(10.9 \%)$ were stratified as inadequate or deficient group $(<16$ $\mathrm{ng} / \mathrm{ml}$ ) with mean survival time of 60.65 months compared to 76.24 months in insufficient or sufficient group ( $\geq 16 \mathrm{ng} /$ $\mathrm{ml}$ ). Multivariate analysis adjusted for age, body mass index, stage, lymph node metastases, and immunohistochemical (IHC) findings (ER, PgR, HER-2, Ki-67 and P53) showed that patients with low 25(OH)D levels ( $<16 \mathrm{ng} / \mathrm{ml})$ at diagnosis had a significantly higher risk of death (hazard ratio $=2.5-2.9)$ than the group with high $25(\mathrm{OH}) \mathrm{D}$ levels $(\geq 16 \mathrm{ng} /$ $\mathrm{ml})$. Conclusion: A concentration of $25(\mathrm{OH}) \mathrm{D}$ below $16 \mathrm{ng} / \mathrm{ml}$ was found to be independently associated with poor survival in breast cancer patients, regardless of age, lymph node status, stage or breast cancer subtype. An investigation of potential benefit of 25(OH)D supplements appears warranted.
\end{abstract}

Keywords: Vitamin D deficiency - 25(OH)D - breast cancer - survival rate - prognosis

Asian Pac J Cancer Prev, 20 (10), 3101-3106

\section{Introduction}

Breast cancer is the leading female cancer worldwide in both incidence and mortality, with an estimated 1.7 million new cases and over half a million deaths in 2012 (Hu et al., 2018). A great deal of effort has been invested in countering this public health problem with implementation of screening mammography, improvement of access to cancer care and development of anti-cancer protocols. However, problems with poor outcome still remain in many countries.

$25(\mathrm{OH}) \mathrm{D}$, a fat-soluble vitamin generated by sunlight exposure or obtained through the diet, plays roles in calcium homeostasis, neuromuscular and immune functions and control of inflammation. Associations of low serum $25(\mathrm{OH}) \mathrm{D}$ with cancer incidence and mortality are in line with its anti-cancer properties (Lim et al., 2015), with contributions to regulation of cell growth and apoptosis (Kermani et al., 2011). Epidemiologic studies have generally indicated an inverse association between the $25(\mathrm{OH}) \mathrm{D}$ levels and risk of cancers including breast cancers (Goodwin et al., 2009; Gorham et al., 2007; Crew et al., 2009; Bao et al., 2010; Shui and Giovannucci, 2014). Furthermore, breast cancers in patients with low $25(\mathrm{OH}) \mathrm{D}$ levels (below 30 or $32 \mathrm{ng} / \mathrm{ml}$ ) usually have more aggressive clinico-pathological characteristics that result in a poorer prognosis (Palmieri et al., 2006; Goodwin et al., 2009; Thanasitthichai et al., 2015). However, an optimal 25(OH)D cut-off level for prediction of survival outcome under given clinico-pathological conditions has yet to be established. Therefore, we conducted the present retrospective cohort study of $25(\mathrm{OH}) \mathrm{D}$ levels in breast cancer patients at the National Cancer Institute, Thailand.

\section{Materials and Methods}

\section{Study participants}

In this study, 303 patients newly diagnosed with breast cancer between July 2011 and June 2012 were enrolled. All patients were examined for their baseline $25(\mathrm{OH})$ $\mathrm{D}$ levels both before and after treatment. Analyses were carried out with age, BMI, clinical stage, lymph node 
metastasis, ER, PgR, HER-2, P53, Ki-67 and 25(OH) $\mathrm{D}$ levels as variables. The study was approved by the Institutional Review Board and Ethics Committee of NCI, Thailand. Written informed consent was obtained from all patients.

Serum collection and 25(OH)D levels assessment

Approximately $1.5 \mathrm{ml}$ aliquots of serum were collected from $7 \mathrm{ml}$ whole blood samples of each patient and stored at $-20^{\circ} \mathrm{C}$ until $25(\mathrm{OH}) \mathrm{D}$ concentrations were determined by high-performance liquid chromatography (HPLC) with UV detection at the Department of Immunology at NCI, Thailand ((after (Neyestani et al., 2007)).

\section{Statistical analysis}

The average of serum 25(OH)D levels was included in analysis, which homogeneity of variance by Cochran and Bartlett's test were not different. Adopting cut-off points from the literature (Ross et al., 2011) serum 25(OH) D levels were classified as inadequate or deficient when $<20 \mathrm{ng} / \mathrm{ml}$ (inadequate $12-20 \mathrm{ng} / \mathrm{ml}$, deficient $<12 \mathrm{ng} /$ $\mathrm{ml}$ ), insufficient with $20-30 \mathrm{ng} / \mathrm{ml}$, and sufficient with $>30 \mathrm{ng} / \mathrm{ml}$. The impact of $25(\mathrm{OH}) \mathrm{D}$ deficiency on breast cancer survival was investigated using the $25(\mathrm{OH}) \mathrm{D}$ cut point of $16 \mathrm{ng} / \mathrm{ml}$ (calculated from median of IOM definitions for inadequate $25(\mathrm{OH}) \mathrm{D}, 12-20 \mathrm{ng} / \mathrm{ml}$ ), above and below which patients were respectively considered to have sufficient and deficient levels. Descriptive statistics were applied with the Chi-square test used to evaluate the significance of differences in parameters between groups. Overall survival was calculated from the date of diagnosis to the date of last follow-up or death from any cause. To compare survival times, the Kaplan-Meier method and log-rank test were employed. Univariate and multivariate statistics were used to estimate hazard ratios (HRs) and 95\% confidence intervals (95\% CIs) with the Cox's proportional hazard model. Significance was concluded with p-values $<0.05$.

\section{Results}

The mean age for the 303 patients was $50.8 \pm 10.5$ years (range: $24-78$ years). Their mean $25(\mathrm{OH}) \mathrm{D}$ concentration was $25.1 \pm 7.54 \mathrm{ng} / \mathrm{ml}(8.2-61.0 \mathrm{ng} / \mathrm{ml})$. Thirty-three cases constituted the deficient group $(<16 \mathrm{ng} / \mathrm{ml})$ with a mean serum $25(\mathrm{OH}) \mathrm{D}$ concentration of $13.3 \pm 1.9 \mathrm{ng} / \mathrm{ml}$ $(8.2-15.6 \mathrm{ng} / \mathrm{ml})$. The remaining $270(86.0 \%)$ patients had a mean value of $26.6 \pm 6.7 \mathrm{ng} / \mathrm{ml}(16.0-61.0 \mathrm{ng} / \mathrm{ml})$. Cases with high $25(\mathrm{OH}) \mathrm{D}$ levels $(\geq 16 \mathrm{ng} / \mathrm{ml})$ were mainly early stage or with HER-2 negative status ( $\mathrm{p}=0.042$ and 0.046 , respectively) as detailed in Table 1 .

The mean survival time was 74.8 months, with an overall survival (OS) of $81.5 \%$ at 60 months. Breast cancer patients in the deficient group $(<16 \mathrm{ng} / \mathrm{ml})$ had poorer outcomes for overall survival compared with patients with sufficient $25(\mathrm{OH}) \mathrm{D}(\geq 16 \mathrm{ng} / \mathrm{ml})(\mathrm{p}=0.002)$. In the deficient patients with older age, BMI $(\geq 23 \mathrm{~kg} /$ $\mathrm{m}^{2}$ ), advance stage, lymph node metastasis, negative for $P g R, H E R-2, P 53, K i-67$, and positive for ER showed significantly poorer 5 year-survival rate compared to their sufficient counterparts $(\mathrm{p}=0.003,0.007,0.024$, $0.001,0.001,0.001,0.001,0.027$, and 0.012 , respectively) (Table 2). Figure 1 shows Kaplan-Meier plots. Patients with deficient serum $25(\mathrm{OH}) \mathrm{D}$ levels had a significantly poorer overall survival than the patients with sufficient serum 25(OH)D levels $(p=0.002)$.

We conducted univariate and multivariate analysis to determine risk factors affecting breast cancer survival. The multivariate findings after adjustment for age, body mass index, stage, lymph node metastases, IHC findings (ER, $P g R, H E R-2, K i-67$ and P53) showed that patients with $25(\mathrm{OH}) \mathrm{D}$ levels $<16 \mathrm{ng} / \mathrm{ml}$ at diagnosis had a significantly higher risk of death (hazard ratio $=2.5-2.9$ ) than the group with $25(\mathrm{OH}) \mathrm{D}$ levels $\geq 16 \mathrm{ng} / \mathrm{ml}$ (Table 3 ).

\section{Discussion}

From our analysis, we found that application of a cut-off

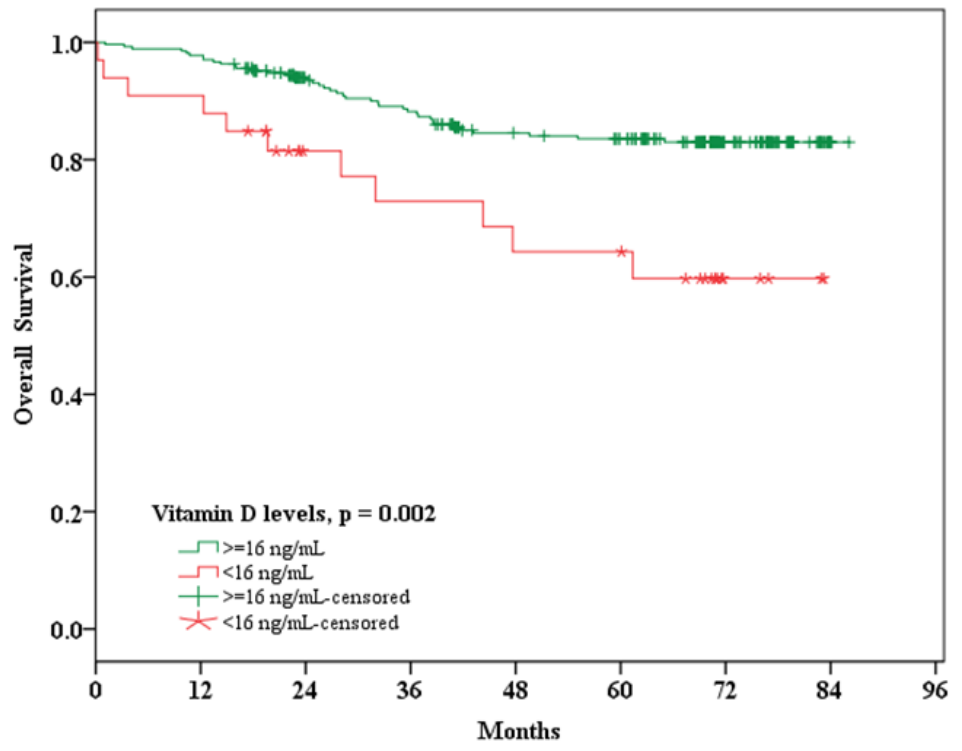

Figure 1. Kaplan-Meier plot for overall survival in breast cancer patients with serum 25(OH)D levels $<16 \mathrm{ng} / \mathrm{ml}$ versus $\geq 16 \mathrm{ng} / \mathrm{ml}$. 
Table 1. Patient Characteristics and 25(OH)D Levels

\begin{tabular}{|c|c|c|c|c|}
\hline Characteristics & $\begin{array}{l}\text { Total } \\
\text { n (\%) }\end{array}$ & $\begin{array}{c}\text { Deficient } \\
(<16 \mathrm{ng} / \mathrm{ml}) \\
\mathrm{n}(\%)\end{array}$ & $\begin{array}{l}\text { Sufficient } \\
(\geq 16 \mathrm{ng} / \mathrm{ml}) \\
\mathrm{n}(\%)\end{array}$ & $\begin{array}{c}\mathrm{p}- \\
\text { value }\end{array}$ \\
\hline \multicolumn{4}{|c|}{ Age group (years) } & \multirow[t]{3}{*}{0.332} \\
\hline$<50$ & $143(47.4)$ & $13(39.4)$ & $130(48.3)$ & \\
\hline$\geq 50$ & $159(52.6)$ & $20(60.6)$ & 139 (51.7) & \\
\hline \multicolumn{4}{|l|}{ BMI $\left(\mathrm{kg} / \mathrm{m}^{2}\right)$} & \multirow[t]{3}{*}{0.424} \\
\hline$<23$ & $128(43.4)$ & $16(50.0)$ & $112(42.6)$ & \\
\hline$\geq 23$ & $167(56.6)$ & $16(50.0)$ & 151 (57.4) & \\
\hline \multicolumn{4}{|l|}{ Clinical Stage } & \multirow[t]{3}{*}{0.042} \\
\hline Stages I-II & $189(69.5)$ & $16(53.3)$ & $173(71.5)$ & \\
\hline Stages III-IV & $83(30.5)$ & $14(46.7)$ & $69(28.5)$ & \\
\hline \multicolumn{4}{|l|}{ LN metastasis } & \multirow[t]{3}{*}{0.49} \\
\hline Positive & 117 (51.3) & $15(57.7)$ & $102(50.5)$ & \\
\hline Negative & 111 (48.7) & $11(42.3)$ & $100(49.5)$ & \\
\hline \multicolumn{4}{|l|}{ ER } & \multirow[t]{3}{*}{0.94} \\
\hline Positive & $170(64.9)$ & $19(65.5)$ & $151(64.8)$ & \\
\hline Negative & $92(35.1)$ & $10(34.5)$ & $82(35.2)$ & \\
\hline \multicolumn{4}{|l|}{ PR } & \multirow[t]{3}{*}{0.776} \\
\hline Positive & $129(49.2)$ & $15(51.7)$ & $114(48.9)$ & \\
\hline Negative & $133(50.8)$ & $14(48.3)$ & $119(51.1)$ & \\
\hline \multicolumn{4}{|l|}{ HER-2 } & \multirow[t]{4}{*}{0.046} \\
\hline Positive & $49(19.2)$ & $6(22.2)$ & 43 (18.9) & \\
\hline Equivocal & $52(20.4)$ & $10(37.0)$ & $42(18.4)$ & \\
\hline Negative & $154(60.4)$ & $11(40.7)$ & $143(62.7)$ & \\
\hline \multicolumn{4}{|l|}{ P53 } & \multirow[t]{3}{*}{0.299} \\
\hline Positive & $206(78.0)$ & $24(85.7)$ & $182(77.1)$ & \\
\hline Negative & $58(22.0)$ & $4(14.3)$ & $54(22.9)$ & \\
\hline \multicolumn{4}{|l|}{ Ki-67 } & \multirow[t]{3}{*}{0.225} \\
\hline Positive & 238 (93.3) & $22(88.0)$ & $216(93.9)$ & \\
\hline Negative & $17(6.7)$ & $3(12.0)$ & $14(6.1)$ & \\
\hline
\end{tabular}

BMI, body mass Index; LN, lymph node; ER, estrogen receptor; PR, progesterone receptor; HER-2, human epithelial growth factor receptor-2.

value of $16 \mathrm{ng} / \mathrm{ml}$ for serum 25(OH)D levels is appropriate for division of patients regarding risk of mortality. Our findings are in line with other reports that low serum $25(\mathrm{OH}) \mathrm{D}$ has a negative effect on overall and disease-free survival (Ismail et al., 2018; Yao et al., 2017). Moreover, in an additional analysis, by dividing the patients into 3 groups: inadequate $(<16 \mathrm{ng} / \mathrm{ml})$, insufficient $(16-30 \mathrm{ng} /$ $\mathrm{ml})$, and sufficient $(>30 \mathrm{ng} / \mathrm{ml}$ ) levels, we found that not only the patients with serum $25(\mathrm{OH}) \mathrm{D}>30 \mathrm{ng} / \mathrm{ml}$ had no survival benefit from higher $25(\mathrm{OH}) \mathrm{D}$, but also they had worse survival trend compared to the intermediate level (data not shown). This might imply that the vitamin D supplement might have no additional benefit in patients who are not actually deficient.

Investigation of prognostic effects of serum $25(\mathrm{OH})$ $\mathrm{D}$ levels in a prospective cohort of 512 women with early breast cancer, revealed those with serum 25(OH)D levels $<20 \mathrm{ng} / \mathrm{ml}$ had poorer overall survival $(\mathrm{HR}=1.73 ; 95 \%$ CI, 1.05-2.86) compared to those with $>28.8 \mathrm{ng} / \mathrm{ml}$, on univariate analysis. However, no statistical significance was found after adjusting for age, tumor stage, nodal
Table 2. Five Year Overall Survival Proportions with Patient Characteristics According to the Serum 25(OH) D cut-off

\begin{tabular}{|c|c|c|c|c|}
\hline \multirow[t]{2}{*}{ Characteristics } & \multirow[t]{2}{*}{$\mathrm{n}$} & \multicolumn{2}{|c|}{5 -year survival (\%) } & \multirow[t]{2}{*}{ p-value } \\
\hline & & $<16 \mathrm{ng} / \mathrm{ml}$ & $\geq 16 \mathrm{ng} / \mathrm{ml}$ & \\
\hline Vitamin D & 303 & 64.3 & 83.5 & 0.002 \\
\hline Age (years) & & & & 0.003 \\
\hline$<50$ & 143 & 80.8 & 89 & \\
\hline$\geq 50$ & 159 & 54 & 78.2 & \\
\hline BMI $23 \mathrm{~kg} / \mathrm{m}^{2}$ & & & & 0.007 \\
\hline$<23$ & 128 & 81.3 & 75.1 & \\
\hline$\geq 23$ & 167 & 51.9 & 91.9 & \\
\hline Clinical stage & & & & 0.024 \\
\hline I-II & 189 & 81.8 & 92.6 & \\
\hline III-IV & 83 & 42.9 & 61.3 & \\
\hline LN metastasis & & & & 0.001 \\
\hline Positive & 117 & 45 & 72.2 & \\
\hline Negative & 111 & 87.5 & 96.5 & \\
\hline ER & & & & 0.001 \\
\hline Positive & 170 & 52.1 & 86.2 & \\
\hline Negative & 92 & 70 & 77.7 & \\
\hline $\operatorname{PgR}$ & & & & 0.001 \\
\hline Positive & 129 & 61.9 & 90.3 & \\
\hline Negative & 133 & 57.1 & 76.2 & \\
\hline HER-2 & & & & 0.012 \\
\hline Positive & 49 & 62.5 & 70.6 & \\
\hline Equivocal & 52 & 75 & 76 & \\
\hline Negative & 154 & 51.1 & 88.2 & \\
\hline P53 & & & & 0.001 \\
\hline Positive & 206 & 65.5 & 85.7 & \\
\hline Negative & 58 & 50 & 75.6 & \\
\hline Ki-67 & & & & 0.027 \\
\hline Positive & 238 & 67.9 & 82.9 & \\
\hline Negative & 17 & 66.7 & 85.7 & \\
\hline
\end{tabular}

stage, estrogen receptor status, and histological grading on multivariate analysis ( $\mathrm{HR}=1.60 ; 95 \% \mathrm{CI}, 0.96-2.64)$ (Goodwin et al., 2009). In the study by Lim et al. clinico-pathological data were collected for patients, including serum 25(OH)D levels at diagnosis and at annual follow-up until 2012. Patients with advanced stage disease or older age in the non-deficient group ( $\geq 20 \mathrm{ng} /$ $\mathrm{ml}$ ), showed a significantly better survival compared with the deficient group, suggesting that sustaining optimal serum 25(OH)D levels should be advised for breast cancer patients (Lim et al., 2015). In a Norwegian study, patients who were diagnosed with breast cancer with higher serum $25(\mathrm{OH}) \mathrm{D}$ levels $(>35 \mathrm{ng} / \mathrm{ml})$ had a significantly decreased risk of breast cancer-specific mortality compared to those with lower serum 25(OH)D levels $(<20 \mathrm{ng} / \mathrm{ml})$ (Tretli et al., 2012). In a randomized clinical trial patients with high levels of $25(\mathrm{OH}) \mathrm{D}$ prior to chemotherapy had significantly improved overall survival and progression-free survival (Ng et al., 2019).

Mohr et al. also found that high serum 25(OH)D status was associated with lower mortality in patients with breast 
Table 3. Univariate and Multivariate Analyses Evaluating the Baseline Risk Factors that Affect Survival

\begin{tabular}{|c|c|c|c|c|}
\hline & \multicolumn{4}{|c|}{ Overall survival } \\
\hline & Unadjusted HRa $(95 \% \mathrm{CI})$ & p-value & Adjusted HR (95\%CI) & p-value \\
\hline \multicolumn{5}{|l|}{$25(\mathrm{OH}) \mathrm{D}$ levels stratified by age ${ }^{\mathrm{b}}$} \\
\hline Insufficient/sufficient ( $\geq 16$ ng/ml) & Reference & & Reference & \\
\hline Inadequate $(<16$ ng/ml) & $2.626(1.344-5.130)$ & 0.005 & $2.474(1.084-5.644)$ & 0.031 \\
\hline \multicolumn{5}{|l|}{ 25(OH)D levels stratified by BMI ${ }^{c}$} \\
\hline Insufficient/sufficient ( $\geq 16 \mathrm{ng} / \mathrm{ml}$ ) & Reference & & Reference & \\
\hline Inadequate $(<16 \mathrm{ng} / \mathrm{ml})$ & $2.541(1.261-5.122)$ & 0.009 & $2.699(1.161-6.272)$ & 0.021 \\
\hline \multicolumn{5}{|l|}{$25(\mathrm{OH}) \mathrm{D}$ levels stratified by Stage ${ }^{\mathrm{c}}$} \\
\hline Insufficient/sufficient ( $\geq 16$ ng/ml) & Reference & & Reference & \\
\hline Inadequate $(<16 \mathrm{ng} / \mathrm{ml})$ & $2.138(1.086-4.207)$ & 0.028 & $2.429(1.148-5.139)$ & 0.02 \\
\hline \multicolumn{5}{|l|}{ 25(OH)D levels stratified by HER-2 ${ }^{c}$} \\
\hline Insufficient/sufficient ( $\geq 16$ ng/ml) & Reference & & Reference & \\
\hline Inadequate $(<16 \mathrm{ng} / \mathrm{ml})$ & $2.448(1.188-5.045)$ & 0.015 & $2.499(1.095-5.704)$ & 0.03 \\
\hline \multicolumn{5}{|l|}{ 25(OH)D levels stratified by $\mathrm{LN}^{\mathrm{d}}$} \\
\hline Insufficient/sufficient ( $\geq 16$ ng/ml) & Reference & & Reference & \\
\hline Inadequate $(<16 \mathrm{ng} / \mathrm{ml})$ & $3.190(1.557-6.534)$ & 0.002 & $2.493(1.090-5.704)$ & 0.03 \\
\hline \multicolumn{5}{|l|}{ 25(OH)D levels stratified by PR ${ }^{\mathrm{e}}$} \\
\hline Insufficient/sufficient ( $\geq 16$ ng/ml) & Reference & & Reference & \\
\hline Inadequate $(<16 \mathrm{ng} / \mathrm{ml})$ & $2.942(1.494-5.794)$ & 0.002 & $2.559(1.113-5.884)$ & 0.027 \\
\hline \multicolumn{5}{|l|}{ 25(OH)D levels stratified by P53 e } \\
\hline Insufficient/sufficient ( $\geq 16 \mathrm{ng} / \mathrm{ml}$ ) & Reference & & Reference & \\
\hline Inadequate $(<16 \mathrm{ng} / \mathrm{ml})$ & $2.972(1.469-6.014)$ & 0.002 & $2.518(1.098-5.773)$ & 0.029 \\
\hline \multicolumn{5}{|l|}{ 25(OH)D levels stratified by ER ${ }^{\mathrm{f}}$} \\
\hline Insufficient/sufficient ( $\geq 16 \mathrm{ng} / \mathrm{ml}$ ) & Reference & & Reference & \\
\hline Inadequate $(<16 \mathrm{ng} / \mathrm{ml})$ & $3.115(1.581-6.141)$ & 0.001 & $2.966(1.399-6.286)$ & 0.005 \\
\hline \multicolumn{5}{|l|}{ 25(OH)D levels stratified by Ki-67 g } \\
\hline Insufficient/sufficient ( $\geq 16 \mathrm{ng} / \mathrm{ml}$ ) & Reference & & Reference & \\
\hline Inadequate $(<16 \mathrm{ng} / \mathrm{ml})$ & $2.325(1.075-5.031)$ & 0.032 & $2.462(1.050-5.773)$ & 0.038 \\
\hline
\end{tabular}

${ }^{\mathrm{a}}$, Hazard ratio; ${ }^{\mathrm{b}}$, Adjusted for LN, ER, and HER-2; ${ }^{\mathrm{c}}$, Adjusted for age, LN, and ER; ${ }^{\mathrm{d}}$, Adjusted for age, ER, and HER-2; ${ }^{\mathrm{e}}$, Adjusted for age, LN, ER, and HER-2; ${ }^{\mathrm{f}}$, Adjusted for age, LN, and HER-2; , Adjusted for LN and p53"

cancer, recommending that a normal range (30-80 $\mathrm{ng} /$ $\mathrm{ml})$ should be maintained with appropriate monitoring (Mohr et al., 2014). In addition, O'Brien et al., (2017) reported high serum $25(\mathrm{OH}) \mathrm{D}$ levels and regular $25(\mathrm{OH})$ $\mathrm{D}$ supplement use to be associated with lower rates of breast cancer, especially in postmenopausal women. Similar findings were recently published by Estébanez et al., (2018). From a meta-analysis Kim and Je (2014) concluded that high $25(\mathrm{OH}) \mathrm{D}$ status is weakly associated with low breast cancer risk, but strongly associated with better breast cancer survival. Low 25(OH)D levels may be more significantly associated with locally advanced or metastatic breast cancer compared with early stages (Palmieri et al., 2006). Overall, the results support the hypothesis that $25(\mathrm{OH}) \mathrm{D}$ supplementation is useful in breast cancer prevention.

However a cohort study of 585 breast cancer survivors higher serum $25(\mathrm{OH}) \mathrm{D}$ was associated with improved survival, but the result was not statistically significant and interpretation is difficult (Villaseñor et al., 2013). Furthermore, other results did not support recommendations for vitamin D supplementation to improve breast cancer outcome (Lohmann et al., 2015). In a very recent nationwide, randomized, placebo-controlled trial, with a two-by-two factorial design, $25(\mathrm{OH})$ $\mathrm{D}$ (cholecalciferol) at a dose of 2,000 IU per day did not result in a lower incidence of invasive cancer or cardiovascular event than placebo (Manson et al., 2019).

As a strength of this study, we used a longitudinal cohort. As a possible limitation, to should be mentioned that only a single measurement of serum $25(\mathrm{OH}) \mathrm{D}$ levels was made. However, serum $25(\mathrm{OH}) \mathrm{D}$ has been reported to remain relatively stable over time, so this may not cause significantly bias (McKibben et al., 2016; Hu et al., 2018). A previous study found some evidence that serum $25(\mathrm{OH})$ $\mathrm{D}$ varies during the calendar year (Fohner et al., 2016).

For explanation of anticancer effects, $25(\mathrm{OH}) \mathrm{D}$ can regulate the whole process of tumorigenesis from initiation to metastasis and cell-microenvironment interactions. 1 $\alpha, 25$-dihydroxyvitamin $\mathrm{D}\left(1 \alpha, 25(\mathrm{OH})_{2} \mathrm{D}_{3}\right.$, calcitriol) roles are mediated by the vitamin $\mathrm{D}$ receptor (VDR) (Hu et al., 2018). Regulation of apoptosis, autophagy, inhibits cell proliferation, differentiation, epithelial-mesenchymal transition (EMT), and cell-microenvironment interactions 
have been proposed (Jeon and Shin, 2018). Metastasis is a complex and multistep process, during which circulating tumor cell (CTC) spread from the primary tumor mass, in the reversible EMT form to the distant organs. Once distant organs are reached, these mesenchymal tumor cells reverse to an epithelial identity via mesenchymal-epithelial (MET) to regain the ability to proliferate (Thanasitthichai et al., 2015).

Furthermore, vitamin D also activates transcription factors of FoxO protein, which control cell proliferation and survival by inducing deacetylation and dephosphorylation, for example, in neuroblastoma cells (Jeon and Shin, 2018). FoxO is a tumor suppressor associated with longevity. There is evidence that $1 \alpha, 25$-dihydroxyvitamin $\mathrm{D}_{3}$ $\left(1 \alpha, 25(\mathrm{OH})_{2} \mathrm{D}_{3}\right.$, calcitriol) and FoxO regulate common target genes. VDR is linked with FoxO protein and also regulates the sirtuin 1 (Sirt1) class III histone deacetylase (HDAC) and protein phosphatase 1, providing a molecular basis for cancer chemopreventive actions of $1 \alpha, 25(\mathrm{OH})_{2} \mathrm{D}_{3}$ (An et al., 2010). Apoptosis can be induced by 25(OH) $\mathrm{D}$ compound $\left(1 \alpha, 25(\mathrm{OH})_{2} \mathrm{D}_{3}, \mathrm{~EB} 1089\right.$, and $\left.\mathrm{CB} 1093\right)$ inhibited by Bcl-2 in MCF-7 and T47D human breast cancer cells expressing wild-type and mutant p53, respectively. This finding may indicate potential for treatment of tumors that are resistant to therapeutic agents that are dependent on the activation of p53 and/or caspases (Mathiasen et al., 1999).

In conclusion, our findings suggest that low levels of serum $25(\mathrm{OH}) \mathrm{D}$ are significantly associated with poor survival of breast cancer patients. It remains unclear whether adding vitamin D supplement to traditional breast cancer therapy would be a safe way to improve overall survival of breast cancer patients. Further prospective cohort studies and clinical trials are needed for clarification.

\section{Acknowledgments}

We would like to thank you Dr. Malcolm Anthony Moore and Dr. Sunanta Chariyalertsak for being good advisors and preparing the manuscript. This study was supported by a grant from National Cancer Institute, Thailand.

\section{Statement conflict of Interest}

We declare that we have no conflict of interest.

\section{References}

An BS, Tavera-Mendoza LE, Dimitrov V, et al (2010). Stimulation of Sirt1-regulated FoxO protein function by the ligand-bound vitamin D receptor. Mol Cell Biol, 30, 4890-4900.

Bao Y, Ng K, Wolpin BM, et al (2010). Predicted vitamin D status and pancreatic cancer risk in two prospective cohort studies. Br J Cancer, 102, 1422-7.

Crew KD, Gammon MD, Steck SE, et al (2009). Association between plasma 25-hydroxyvitamin D and breast cancer risk. Cancer Prev Res Phila Pa, 2, 598-604.

Estébanez N, Gómez-Acebo I, Palazuelos C, et al (2018). Vitamin $\mathrm{D}$ exposure and risk of breast cancer: a meta-analysis. $\mathrm{Sci}$ Rep, 8, 9039.
Fohner AE, Wang Z, Yracheta J, et al (2016). Genetics, diet, and season are associated with serum 25 -hydroxycholecalciferol concentration in a Yup'ik study population from Southwestern Alaska. J Nutr, 146, 318-25.

Freedman DM, Looker AC, Chang SC, et al (2007). Prospective study of serum vitamin D and cancer mortality in the United States. J Natl Cancer Inst, 99, 1594-1602.

Goodwin PJ, Ennis M, Pritchard KI, et al (2009). Prognostic effects of 25-hydroxyvitamin D levels in early breast cancer. J Clin Oncol, 27, 3757-63.

Gorham ED, Garland CF, Garland FC, et al (2007). Optimal vitamin D status for colorectal cancer prevention: a quantitative meta analysis. Am J Prev Med, 32, 210-6.

Hu K, Callen DF, Li J, et al (2018). Circulating vitamin D and overall survival in breast cancer patients: a dose-response meta-analysis of cohort studies. Integr Cancer Ther, 17, 217-25.

Ismail A, El-Awady R, Mohamed G, et al (2018). Prognostic significance of serum vitamin D levels in Egyptian females with breast cancer. Asian Pac J Cancer Prev, 19, 571-6.

Jeon SM, Shin EA (2018). Exploring vitamin D metabolism and function in cancer. Exp Mol Med, 50, 20.

Kermani IA, Kojidi HT, Gharamaleki JV, et al (2011). Association of serum level of 25 hydroxy-vitamin $\mathrm{D}$ with prognostic factors for breast cancer. Asian Pac J Cancer Prev, 12, 1381-4.

Kim Y, Je Y (2014). Vitamin D intake, blood 25(OH)D levels, and breast cancer risk or mortality: a meta-analysis. $\mathrm{Br} J$ Cancer, 110, 2772-84.

Lim ST, Jeon YW, Suh YJ (2015). Association between alterations in the serum 25-hydroxyvitamin D status during follow-up and breast cancer patient prognosis. Asian Pac J Cancer Prev, 16, 2507-13.

Lohmann AE, Chapman JAW, Burnell MJ, et al (2015). Prognostic associations of 25 hydroxy vitamin D in NCIC CTG MA.21, a phase III adjuvant randomized clinical trial of three chemotherapy regimens in high-risk breast cancer. Breast Cancer Res Treat, 150, 605-11.

Manson JE, Cook NR, Lee IM, et al (2019). Vitamin D supplements and prevention of cancer and cardiovascular disease. $N$ Engl J Med, 380, 33-44.

Mathiasen IS, Lademann U, Jäättelä M (1999). Apoptosis induced by vitamin D compounds in breast cancer cells is inhibited by Bcl-2 but does not involve known caspases or p53. Cancer Res, 59, 4848-56.

McKibben RA, Zhao D, Lutsey PL, et al (2016). Factors associated with change in 25-hydroxyvitamin D levels over longitudinal follow-Up in the ARIC Study. J Clin Endocrinol Metab, 101, 33-43.

Mohr SB, Gorham ED, Kim J, et al (2014). Meta-analysis of vitamin D sufficiency for improving survival of patients with breast cancer. Anticancer Res, 34, 1163-6.

Neyestani TR, Gharavi A, Kalayi A (2007). Determination of serum 25-hydroxy cholecalciferol using high-performance liquid chromatography: a reliable tool for assessment of vitamin D status. Int J Vitam Nutr, 77, 341-6.

$\mathrm{Ng} \mathrm{K}$, Nimeiri HS, McCleary NJ, et al (2019). Effect of high-dose vs standard-dose vitamin D3 supplementation on progression-free survival among patients with advanced or metastatic colorectal cancer: The SUNSHINE Randomized Clinical Trial. JAMA, 321, 1370-9.

O'Brien KM, Sandler DP, Taylor JA, et al (2017). Serum vitamin $\mathrm{D}$ and risk of breast cancer within five Years. Environ Health Perspect, 125, 077004.

Palmieri C, MacGregor T, Girgis S, et al (2006). Serum 25-hydroxyvitamin D levels in early and advanced breast cancer. J Clin Pathol, 59, 1334-6. 
Ross AC, Taylor CL, Yaktine AL, et al (2011). The 2011 report on dietary reference intakes for calcium and vitamin D from the Institute of Medicine: what clinicians need to know. J Clin Endocrinol Metab, 96, 53-8.

Shui I, Giovannucci E (2014). Vitamin D status and cancer incidence and mortality. Adv Exp Med Biol, 810, 33-51.

Thanasitthichai S, Chaiwerawattana A, Prasitthipayong A(2015). Association of vitamin D level with clinicopathological features in breast cancer. Asian Pac J Cancer Prev, 16, 4881-3.

Tretli S, Schwartz GG, Torjesen PA, et al (2012). Serum levels of 25-hydroxyvitamin D and survival in Norwegian patients with cancer of breast, colon, lung, and lymphoma: a population-based study. Cancer Causes Control, 23, 363-70.

Villaseñor A, Ballard-Barbash R, Ambs A, et al (2013). Associations of serum 25-hydroxyvitamin $\mathrm{D}$ with overall and breast cancer-specific mortality in a multiethnic cohort of breast cancer survivors. Cancer Causes Control, 24, 759-67.

Yao S, Kwan ML, Ergas IJ, et al (2017). Association of serum level of vitamin $\mathrm{D}$ at diagnosis with breast cancer survival: a case-cohort analysis in the pathways study. JAMA Oncol, 3, 351-7.

\section{(c) (1) (8)}

This work is licensed under a Creative Commons AttributionNon Commercial 4.0 International License. 